\title{
Differentiated Thyroid Carcinoma in Children and Adolescents
}

\author{
Jay K. Harness, M.D., Norman W. Thompson, M.D., Michael K. McLeod, M.D., Janice L. Pasieka, M.D., \\ and Atsushi Fukuuchi, M.D. \\ Department of Surgery, Division of Endocrine Surgery, University of Michigan Medical Center, Ann Arbor, Michigan, U.S.A.
}

\begin{abstract}
From 1936 to 1990,89 children and adolescents ( 72 girls and 17 boys) Were treated for differentiated thyroid carcinoma at the University of Michigan Medical Center; 58 of these patients were first reported in 1971. Thirty $(\mathbf{3 4} \%)$ patients had previously received external irradiation to the head and neck, although only $1(3 \%)$ patient of the last 33 patients seen had this history. Patients first presenting from 1971 to 1990 had less advanced disease than those seen earlier. Also, during this time period, the rate of initial palpable cervical adenopathy fell from $63 \%$ to $36 \%$, local infiltration of primary cancer from $31 \%$ to $6 \%$, and initial pulmoary metastases from $19 \%$ to $6 \%$. The incidence of cervical nodal metastases has remained $88 \%$ for 54 years. Papillary or the follicular variant of papillary carcinoma was found in $93 \%$ of all patients. Seventyhine $(89 \%)$ patients had total or completion total thyroidectomy. Surgical management of lymphatic metastases varied from regional excision of nodes to radical neck dissection. The overall rate of permanent accidental recurrent laryngeal nerve palsy and hypoparathyroidism was $4.5 \%$, although neither has occurred in a child or adolescent undergoing surgery at the center in the past 25 years. The most recent 33 patients had a low rate of local/regional persistence or recurrence. Cervical nodal persistence of parred in $21 \%$; there were no thyroid recurrences. Eighty-two percent catients received ${ }^{131} \mathrm{I}$. The long-term mortality rate was $2.2 \%$. We and and postoperative ${ }^{131}$ I therapy as the most conservative treatment regimen for children with differentiated thyroid carcinoma.
\end{abstract}

Differentiated thyroid carcinoma (DTC) in children and adolescents is an uncommon disease with a generally favorable prognosis and a high incidence of cervical metastasis. The association of thyroid carcinoma with the administration of external low-dose irradiation to the head and neck area during childhood has been well documented [1]. The rapid increase in reports on children with DTC began in 1935 and peaked in 1955 . Winship and Rosvoll [1] observed a mean latency period of 8 years between exposure to irradiation and detection of thyroid carcinoma. Although radiation treatment of various benign conditions has been abandoned, cases of childhood DTC continue to be identified.

There is a high rate of local/regional disease in childhood DTC, but the overall mortality remains low [2-7]. Controversy in

Presented at the International Association of Endocrine Surgeons in Rockholm, Sweden, August, 1991.

Suprint requests: Norman W. Thompson, M.D., Department of

Center, University of Michigan Medical Center, 1500 East Medical

enter Drive, Ann Arbor, Michigan 48109-0331, U.S.A. continues over the appropriate extent of thyroid surgery for DTC in adults, in whom mortality can be considerably higher. Given the lack of unanimity about operative therapy in adults, it is understandable that the debate is more intense with respect to children. Some authors argue that total thyroidectomy constitutes an over-treatment that is associated with a high rate of morbidity [5, 6]. Others maintain the total thyroidectomy has an acceptably low rate of morbidity while providing a lower incidence of local/regional recurrence, enhancing the efficacy of radioactive iodine $\left({ }^{131} I\right)$ therapy, and improving mortality $[2-4$, 7].

To address these issues, we reviewed the experience at the University of Michigan Medical Center with childhood DTC during the past 54 years, with emphasis on surgical management, control of local/regional disease, and the long-term results of treatment.

\section{Material and Methods}

We studied children and adolescents (maximum age, 18 years) in whom thyroid carcinoma was diagnosed at the University of Michigan Medical Center during the 54-year period from 1936 to 1990. Of this total population of 110 patients, 58 patients were reported in 1971 [2]. The other 52 patients were subsequently identified through a computerized database maintained by the cancer registry at the University of Michigan Medical Center. Nineteen patients were excluded from this study either because they had medullary carcinoma ( 7 patients); they had not been treated, but only evaluated, at the medical center ( 5 patients); their medical records were incomplete ( 3 patients); or they were lost to follow-up (4 patients). Therefore, 89 patients with childhood differentiated thyroid carcinoma are described here.

The thyroid neoplasms were classified either as papillary, the follicular variant of papillary, or follicular carcinomas on the basis of predominant histologic findings.

The thyroid surgery performed included total thyroidectomy, completion total thyroidectomy, and subtotal thyroidectomy. Subtotal thyroidectomy was defined as any less-than-complete removal of the gland. The surgical management of lymphatic metastases consisted of various regional dissections, ranging from a complete cleaning of upper mediastinal, bilateral peritracheal, and jugular lymphatic chains, to excision of one or 
Table 1. Patient characteristics.

\begin{tabular}{llll}
\hline Characteristic & $1936-1970$ & $1971-1990$ & $\begin{array}{l}\text { Total } \\
\text { series }\end{array}$ \\
\hline No. of pts. & 56 & 33 & 89 \\
Sex (M/F) & $13 / 43$ & $4 / 29$ & $17 / 72$ \\
$\quad$ M/F ratio & $1 / 3.3$ & $1 / 7.3$ & $1 / 4.2$ \\
Average age (yrs) & 12.4 & 13.3 & 12.8 \\
$\quad$ Age range & $3-18$ yr & 6 mo-18 yr & 6 mo-18 yr \\
History of head/neck irradiation & $50 \%$ & $3 \%$ & $34 \%$ \\
Palpable thyroid nodule/mass & $37 \%$ & $73 \%$ & $51 \%$ \\
Palpable cervical adenopathy & $63 \%$ & $36 \%$ & $53 \%$ \\
Local infiltration & $31 \%$ & $6 \%$ & $21 \%$ \\
$\quad$ of primary cancer & & & \\
Initial pulmonary metastases & $19 \%$ & $6 \%$ & $15 \%$ \\
\hline
\end{tabular}

M: male; F: female.

more individually involved lymph nodes ("lymph node plucking"). Modified radical dissection of the neck included excision of all lateral neck lymph nodes with preservation of the sternocleidomastoid muscle and the spinal accessory nerve. In some cases, the internal jugular vein was also preserved.

Nondefinitive, adjuvant, or palliative treatment included excisional biopsy of lymph nodes, thyroid hormone suppression therapy, and radioiodine therapy.

In order to obtain a maximal amount of follow-up information, all living patients were contacted directly by the cancer registry, evaluated by their personal physician, or examined at the medical center.

\section{Results}

Age, Sex, and Year of Diagnosis

Overall, there were 72 female and 17 male patients, with a male-to-female ratio of 1:4.2 (Table 1). However, from 1971 to 1990 , there was an increase in female patients, with the maleto-female ratio becoming 1:7.3. The average age among all patients was 12.8 years.

The year of diagnosis of thyroid carcinoma throughout the series is shown in 5-year increments in Figure 1. In general, the number of diagnoses increased from 1935 to 1965 , decreased through the early 1970s, and began to increase again after 1975 .

\section{Irradiation of Head and Neck}

Thirty (34\%) of the 89 patients had previously received external irradiation to the head and neck, but only 1 of the last 33 patients seen had undergone this procedure. This dramatic decrease apparently resulted from widespread publicity regarding the association between low-dose external irradiation and the subsequent development of thyroid carcinoma.

\section{Extent of Disease at Initial Surgery}

The most common presenting signs of thyroid carcinoma were palpable cervical adenopathy, a palpable thyroid nodule or mass, or both (Table 1). Interestingly, in the 56 patients reported in 1971, cervical adenopathy was the most common sign, whereas in the 33 patients seen most recently, a palpable thyroid nodule or mass was most frequently reported.
At the time of initial surgery, $19(21 \%)$ of 89 patients had extension of primary tumor into the trachea or surrounding soft tissues, including the areas adjacent to or surrounding the recurrent laryngeal nerves. Only 2 of the last 33 patients seen had such extensive local involvement.

Thirteen (15\%) patients had pulmonary metastases at the time of initial surgery, with the diagnosis established by a combination of chest radiography or radioactive iodine scanning of the head, neck, and lungs 6 weeks postoperatively. Only 2 of the 33 patients seen since 1971 had such spread of disease.

\section{Histopathology}

Eighty-three $(93 \%)$ thyroid carcinomas were either pure papillary or the follicular variant of papillary lesions. Six neoplasms were exclusively follicular in nature, with only 1 such lesion found in the past 20 years.

Throughout the entire 54-year history of this series, the occurrence of metastases to cervical lymph nodes has remained constant at $88 \%$ (Table 2). Affected lymph nodes have been found in the following locations: central compartment, jugular chain, lower spinal accessory chain, supraclavicular area, and anterior superior mediastinum.

\section{Treatment}

Seventy-nine patients underwent total thyroidectomy or a completion total thyroidectomy (Table 3). Subtotal thyroidectomy was used in only 5 patients. Five others underwent less extensive procedures, including excisional lymph node biopsy, emergency tracheostomy, and total lobectomy.

The procedures performed for surgical management of lymphatic metastases varied considerably from regional excision of nodes to formal radical neck dissections. Since 1965, no patient has undergone a radical neck dissection at our medical center. Many patients had bilateral procedures. Patients underwent the lymph node procedures at various points in their therapy, including the time of initial surgery, during completion total thyroidectomy, or at resection of persistent or recurrent disease.

\section{Operative Complications}

There were no deaths directly related to any operative procedure, although 2 children, both 3 years old, died within days of tracheostomies done as palliation for respiratory tract insufficiency due to advanced cancer involving the airways and lungs.

Permanent accidental recurrent laryngeal palsy occurred in 5 patients, including 1 patient who sustained the injury at an outside hospital. In the past 25 years, no patient undergoing primary or completion total thyroidectomy at our institution has had this complication.

Six patients have permanent hypoparathyroidism. In 2 patients this developed before their transfer to our medical center. The other 4 patients had extensive bilateral regional lymph node metastases and local infiltration of the primary tumor on at least 1 side; all were operated on before 1965 . In no case was removal or injury of the 4 parathyroids intentional. During the past 25 years, permanent hypoparathyroidism has not developed in any child or adolescent undergoing surgery at our center. 


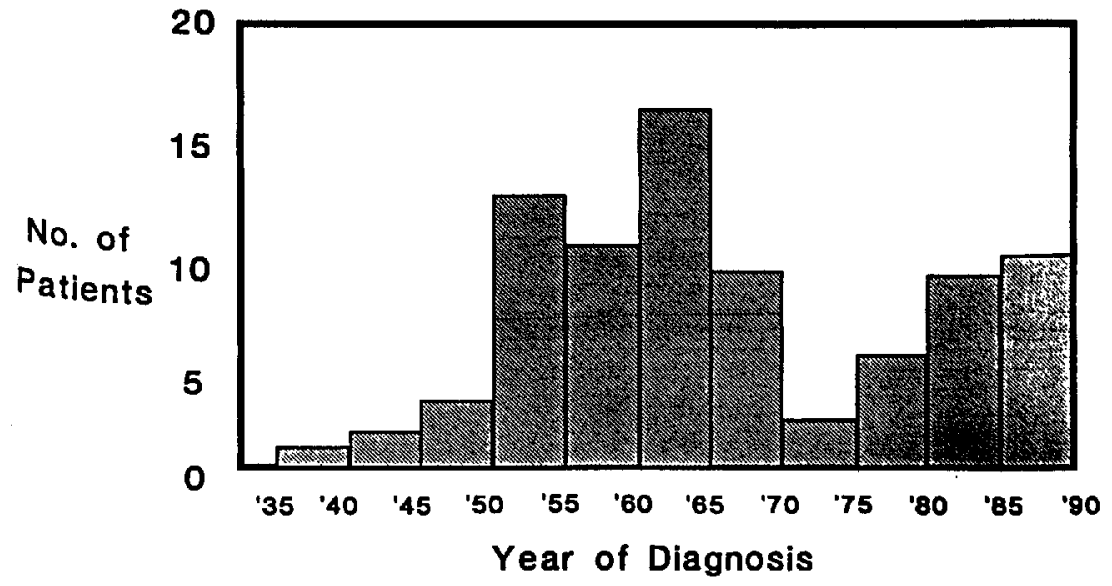

Fig. 1. Patients with childhood differentiated thyroid carcinoma treated at the University of Michigan Medical Center, 1935-1990.

Table 2. Histopathologic findings.

\begin{tabular}{|c|c|c|c|c|c|c|}
\hline \multirow[b]{2}{*}{ Histopathology } & \multicolumn{2}{|c|}{ 1936-1970 } & \multicolumn{2}{|c|}{ 1971-1990 } & \multicolumn{2}{|c|}{ Total series } \\
\hline & $\bar{n}$ & $\overline{(\%)}$ & $\overline{\mathrm{n}}$ & $(\%)$ & $n$ & $(\%)$ \\
\hline $\begin{array}{l}\text { Papillary or follicular variant of papillary } \\
\text { Follicular } \\
\text { Cervical nodal metastases }\end{array}$ & $\begin{array}{r}51 \\
5 \\
49\end{array}$ & $\begin{array}{r}(91) \\
(9) \\
(88)\end{array}$ & $\begin{array}{r}32 \\
1 \\
29\end{array}$ & $\begin{array}{r}(97) \\
(3) \\
(88)\end{array}$ & $\begin{array}{r}83 \\
6 \\
78\end{array}$ & $\begin{array}{r}(93) \\
(7) \\
(88)\end{array}$ \\
\hline
\end{tabular}

Table 3. Surgical treatment and complications.

\begin{tabular}{|c|c|c|c|}
\hline Treatment/complication & $1936-1970$ & $1971-1990$ & $\begin{array}{l}\text { Total } \\
\text { series }\end{array}$ \\
\hline \multicolumn{4}{|l|}{ Surgical treatment } \\
\hline Total thyroidectomy & 49 & 30 & 79 \\
\hline Subtotal thyroidectomy & 2 & 3 & 5 \\
\hline Lobectomy or other procedure & 5 & 0 & 5 \\
\hline $\begin{array}{l}\text { Lymph node plucking or } \\
\text { regional node } \\
\text { excision/bilateral }\end{array}$ & $22 / 7$ & $20 / 4$ & $42 / 11$ \\
\hline $\begin{array}{l}\text { Modified radical neck } \\
\text { dissection/bilateral }\end{array}$ & $10 / 6$ & $11 / 4$ & $21 / 10$ \\
\hline Radical neck dissection & 10 & $2^{a}$ & 12 \\
\hline $\begin{array}{l}\text { Combinations of dissections } \\
\text { Operative complication }\end{array}$ & 2 & 3 & 5 \\
\hline $\begin{array}{l}\text { Permanent accidental recurrent } \\
\text { laryngeal nerve palsy }\end{array}$ & $7 \%$ & $0 \%$ & $4.5^{b}$ \\
\hline Permanent hypoparathyroidism & $8 \%$ & $0 \%$ & $4.5^{b}$ \\
\hline
\end{tabular}

Table 4. Radioactive iodine therapy.

\begin{tabular}{lccc} 
Treatment & $1936-1970$ & $1971-1990$ & Total series \\
\hline $\begin{array}{l}\text { No. of pts. (\%) } \\
\text { Average dose in } \mathrm{mCi}\end{array}$ & $212(88)$ & $24(73)$ & $73(82)$ \\
(range) & & $147(56-600)$ & $180(50-654)$ \\
\hline
\end{tabular}

\section{Radioactive Iodine Therapy}

${ }^{131}$ I was administered in therapeutic doses to $73(82 \%)$ patients (Table 4). Thirteen patients with metastases received more than $300 \mathrm{mCi}$, administered in up to 11 fractionated doses. The largest total dose of ${ }^{131} \mathrm{I}$ received by any patient in this series was $654 \mathrm{mCi}$, given in 5 doses over a 6-year period to treat pulmonary metastases.

\section{Survival}

Four patients treated at our center have died of differentiated thyroid carcinoma in the past 54 years. Two were 3-year-old children who were critically ill from respiratory tract insufficiency on initial presentation to our institution. Both died within days after palliative tracheostomies. The third death was an 11-year-old boy who had extensive bilateral pulmonary metastases and chronic bronchiectasis when first seen. He was treated with total thyroidectomy, bilateral modified radical neck dissections, and more than $300 \mathrm{mCi}$ of ${ }^{131} \mathrm{I}$. He died 7 years later from progressive pulmonary insufficiency due to bronchiectasis and pulmonary metastases. He was never disease-free.

The fourth death was a female who first presented at the age of 6 years with a left thyroid mass and pulmonary metastases. She had received thymic irradiation during her first year of life (in 1948). The patient was treated at an outside hospital with a left thyroid lobectomy followed by $3,000 \mathrm{rad}(30 \mathrm{~Gy}$ ) of external radiation to the neck. She was subsequently referred to our center for completion total thyroidectomy and ${ }^{131} \mathrm{I}$ therapy. The patient received $400 \mathrm{mCi}$ of ${ }^{131} \mathrm{I}$ in 11 doses over a 6-year period, with complete clearing of metastases for 20 years. The pulmonary metastases then recurred and she was treated with chemotherapy. She died at 36 years of age, 30 years after her initial diagnosis and treatment.

The 2 deaths of long-term survivors occurred an average of 18.5 years after initial therapy.

The overall mortality rate for the series is $4.5 \%$, although if the deaths of the 2 critically ill 3-year-old patients are excluded, the long-term mortality is $2.2 \%$. There have been no deaths of 
long-term survivors treated at our institution in the past 20 years.

\section{Local and Distant Recurrence}

Among the 33 patients treated since 1971, 8 patients have had regional neck recurrences; 1 patient had recurrence in the thyroid and 7 patients had recurrence in cervical or anterior superior mediastinal nodes. The average time to regional recurrence was 15 months (range 2-72 months). In 2 patients, pulmonary metastases developed an average of 16.5 months (range 10-23 months) after initial therapy.

The patient with a recurrence in the thyroid was a 6-year-old boy who had undergone a right total thyroid lobectomy at 6 months of age for a "benign follicular adenoma." Six years later, the patient was found to have a $1.5 \mathrm{~cm}$ nodule in the left lobe of his thyroid and a left total lobectomy was performed. Histopathologic evaluation of the excised left lobe revealed papillary carcinoma. A re-analysis of the previously removed right lobe showed follicular variant of papillary carcinoma, rather than adenoma. This case therefore represents a missed diagnosis; the patient should have undergone a total thyroidectomy initially.

The 7 patients who had regional lymph node recurrences had surgical excision of the affected tissue an average of 6 months (range 2-9 months) after their thyroidectomies. These patients probably should be classified as having had persistent disease rather than true recurrence, since their initial lymph node resections consisted of lymph node samplings in 5 patients, modified radical neck dissection in 1 patient and bilateral modified radical neck dissection in 1 patient. Two of the 7 patients had their initial lymph node excisions done at outside hospitals, including the patient who was recorded as having had bilateral modified neck dissections.

In 1 patient in whom persistent disease was resected at 2 months, a true recurrence developed in the anterior superior mediastinum 3 years later. This was successfully treated with ${ }^{131} \mathrm{I}$. The 2 patients in whom pulmonary metastases developed after initial treatment underwent total thyroidectomy and extensive neck dissection. In addition, both were treated with ${ }^{131} \mathrm{I}$ (average dose $360 \mathrm{mCi}$ ). All 4 patients with pulmonary metastases treated since 1971 are alive; 1 patient is disease-free. Overall, their average survival time is 73.5 months (range 13-137 months). They have received an average total dose of $351 \mathrm{mCi}$ of ${ }^{131} \mathrm{I}$ (range 175-518).

\section{Discussion}

We found that since 1971 childhood DTC has changed considerably with respect to etiology and extent of disease at initial presentation. Before 1971 , $50 \%$ of our patients had received low-dose head and neck irradiation. The use of such therapy contributed substantially to the peak in the number of patients seen from 1960 to 1965 (Fig. 1), whereas its abandonment was largely responsible for the decrease in patients occurring by 1970 . Since 1971 , only 1 of our patients, a 15 -year-old girl who underwent thymic irradiation as an infant, had undergone irradiation. This pattern of patient distribution is similar to that reported by Winship and Rosvoll [1]. Interestingly, however, there has been a steady increase in the number of new patients seen since 1970 (Fig. 1). This appears to be due to our referral pattern and not necessarily to an increase in the incidence of childhood DTC.

Before 1971, the most common presenting sign in this series was cervical adenopathy. Since 1971, however, the most common sign has been a palpable thyroid nodule or mass (Table 1). This change in presentation may reflect an increased awareness by pediatricians of the importance of routine physical examination of the thyroid. In the past two decades, the percentages of patients with local infiltration by the primary cancer and of those presenting with pulmonary metastases have fallen dramatically (Table 1), probably because of the earlier diagnosis of childhood DTC.

The reason for the change in the male-to-female ratio of patients with childhood DTC is unclear. Perhaps it reflects the natural history of disease that has not been influenced by radiation therapy.

Our histopathologic data reveal that childhood DTC is almost exclusively papillary or the follicular variant of papillary carcinoma. Pure follicular carcinoma is very rare in patients $<19$ years of age. Our only case in the past 20 years was in a 12 -year-old girl who presented with a thyroid nodule $(1.0 \times 1.0$ $\mathrm{cm}$ ) and no cervical adenopathy. She underwent total thyroidectomy and lymph node sampling. The pathological evaluation showed follicular carcinoma with no nodal metastases. The lesion remains the smallest follicular carcinoma we have ever found in a child or an adult. The patient was treated with 151 $\mathrm{mCi}$ of ${ }^{131} \mathrm{I}$ for residual uptake in the thyroid bed and is disease-free after 5 years of follow-up.

The rate of histopathologically proved cervical metastases in our series has remained constant for 54 years. Our 1971 report was criticized for finding a high incidence of cervical nodal metastases ( $88 \%$ ). However, papillary (or the follicular variant of papillary) carcinoma initially spreads by lymphatic channels. Since virtually all childhood DTC is of this histologic type, it is not surprising that such a high percentage of the patients we have seen recently have cervical metastases. Our findings in this regard are similar to those of studies published in the past 4 years (Table 5) [4-6, 8]. Although, since 1971, we have found less advanced disease at presentation, microscopic nodal metastases do appear to occur early.

The appropriate extent of thyroidectomy for DTC continues to be actively debated, especially with respect to children and adolescents. Some authors [5, 6] strongly support subtotal thyroidectomy and appropriate cervical lymph node dissections. We and others [2-4, 7] support total (or near-total) thyroidectomy plus cervical lymph node dissection. Supporters of the subtotal procedure have argued that total thyroidectomy does not improve overall mortality, but does increase permanent hypoparathyroidism and recurrent laryngeal nerve injury. Total thyroidectomy has been called "aggressive" therapy for a disease that has a favorable prognosis when treated with a less-than-total procedure. It has also been labeled unnecessary therapy for childhood DTC and classified as radical in comparison to the "conservative" subtotal thyroidectomy.

For the past 25 years, we have aimed to treat all cases of DTC (whether in adults or children) uniformly with total thyroidectomy. For 20 years, nearly all thyroidectomies have been done by members of our Division of Endocrine Surgery. This has resulted not only in a consistent approach but also in an 
Table 5. Extent of disease at thyroidectomy and recurrence.

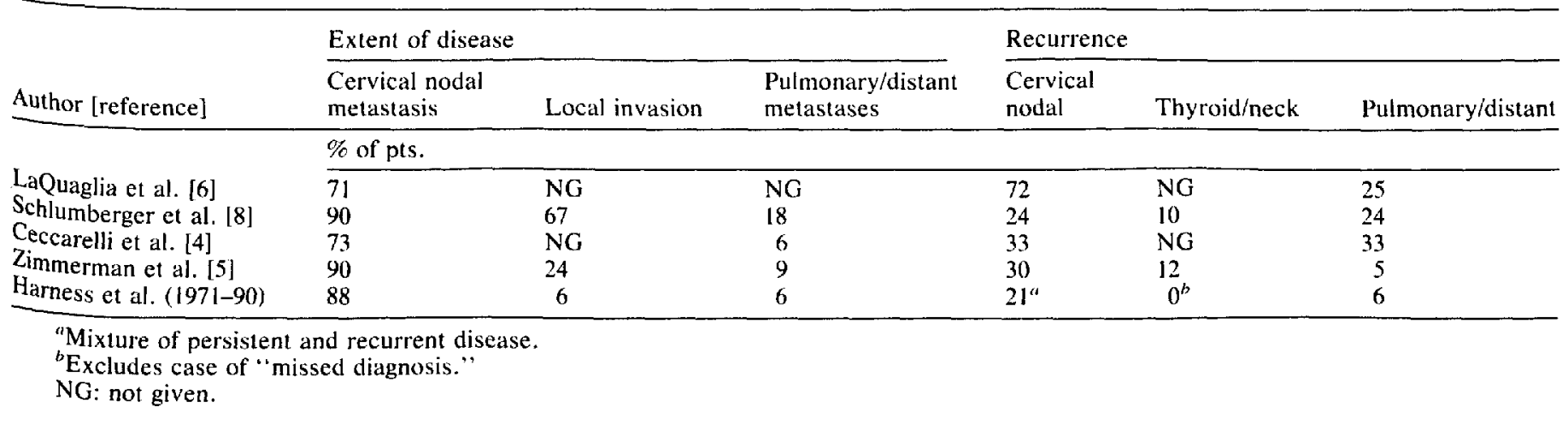

Table 6. Total thyroidectomy and complication rates.

\begin{tabular}{|c|c|c|c|c|c|c|c|}
\hline Author [reference] & $N$ & \multicolumn{2}{|c|}{ Total thyroid" } & \multicolumn{2}{|c|}{ Permanent hypopara" } & \multicolumn{2}{|c|}{ Laryngeal nerve injury } \\
\hline LaQuaglia et al. [6] & 100 & 46 & (46) & 15 & (15) & 14 & (I4) \\
\hline Ceccarelli et al. [4] & 49 & 49 & $(100)$ & 13 & $(27)$ & 12 & (24) \\
\hline Goepfert et al. [7] & 66 & 63 & (95) & 11 & (17) & 0 & (0) \\
\hline Zimmerman et all. [5] & 58 & 22 & (38) & 14 & (24) & 0 & (0) \\
\hline Harness et al. (1970) [2] & 56 & 49 & (88) & 4 & (7) & 4 & (7) \\
\hline
\end{tabular}

"Total or near-total thyroidectomy.

${ }^{b}$ Postoperative permanent hypoparathyroidism.

'Postoperative accidental recurrent laryngeal nerve palsy.

excellent operative safety record. Table 6 shows the figures for total or near-total thyroidectomy in 6 large series of patients with childhood thyroid carcinoma, as well as the incidence of 2 types of complications. Overall, the average rates were $15 \%$ for hypoparathyroidism and $9 \%$ for recurrent laryngeal nerve palsy. In contrast, among the 33 patients most recently undergoing total thyroidectomy and nodal discussion at our center, We have had no such complications (Tables 3 and 6).

It is important to note that complications increase with more locally advanced disease. Schlumberger and coworkers [8] and Zimmerman and associates [5] reported high rates of cervical metastases and local invasion and had a similar incidence of complications (Tables 5 and 6).

At our center, there have been no permanent accidental injuries to recurrent laryngeal nerves in the past 25 years. We take great care to resect tumor surrounding or encasing these nerves. Our philosophy of nerve preservation and our practice of "shaving" tumor off a functioning nerve and subsequently ablating any remaining tumor with ${ }^{131} 1$ have eliminated permanent recurrent laryngeal nerve injuries.

One type of complication that is not often discussed is the "emotional" morbidity associated with repeated operations for local/regional recurrences. We have found that re-operations cause a great deal of emotional anxiety to both patients and their parents. Thus, a decrease in the need for such procedures would provide an important quality-of-life benefit.

Total thyroidectomy reduces the rate of recurrence in the thyroid bed to zero. Our only case of thyroid recurrence was actually an instance of misdiagnosis in a 6-month-old boy who underwent a total right lobectomy performed for a follicular adenoma that, on re-examination 6 years later when a nodule developed in his remaining lobe, was found to be the follicular variant of papillary carcinoma. The new nodule was a papillary cancer. This patient should have had a total thyroidectomy initially instead of a completion total thyroidectomy later.

Regional lymph node recurrence is a common problem in patients with childhood DTC (Table 5) [2, 4-8]. Among our most recent 33 patients, 7 had regional recurrence or persistence of disease. Persistent disease was found an average of 6 months after total or completion total thyroidectomy. Each of the 7 patients required only 1 additional operation to resect their affected nodes. One patient had both persistent disease (resected at 2 months) and a ${ }^{131}$ I-detected anterior mediastinal recurrence (found at 3 years). The mediastinal recurrence was successfully eradicated with a $200 \mathrm{mCi}$ dose of ${ }^{131} \mathrm{I}$.

Our experience suggests that subsequent regional lymph node recurrence is related to the extent of initial disease as well as the scope of the initial node dissection. Patients whose lymph nodes are found to be affected within a year of thyroidectomy should probably be considered to have persistent or "missed" disease as a result of inadequate previous lymph node exploration and resection. Frankenthaler and coworkers [9] observed that DTC in young patients can involve any of the cervical and upper mediastinal nodal groups except the submental, submaxillary, and upper and lower spinal accessory. Schlumberger and colleagues [8] found anterior superior mediastinal involvement only in patients with involvement of the recurrent laryngeal nerve chain (peritracheal). Typically, carcinomas in the upper 
$1 / 3$ of the thyroid gland metastasize to the middle and upper jugular chain. Carcinomas in the lower $2 / 3$ may spread to the middle and lower jugular chain, the central compartment nodes (pretracheal and peritracheal nodes between the jugular veins), or the anterior superior mediastinal nodes.

We explore and sample lymph nodes in areas of likely spread. If involved nodes are found in the central compartment region, we perform a complete dissection from the level of the thyroid notch (Delphian node) to and including the anterior superior mediastinum. If jugular nodes are affected, the entire jugular chain is explored, including the region of the lower spinal accessory nerve. All clinically involved nodes are resected, and bilateral explorations and resections are done if indicated by the extent of disease. We and others $[5,8,9]$ have found that there is a high probability of multiple-node involvement.

Although regional lymph node recurrence or persistence has occurred in some of our patients, we have the lowest incidence in all the most recently reported large series (Table 5) [2, 4-8]. Furthermore, we have reduced emotional morbidity among our patients because none have required more than 1 additional operation to resect their disease.

Initial and subsequent pulmonary metastases occur in childhood DTC although, fortunately, the incidence of spread is decreasing. Most authors agree that total thyroidectomy is indicated when pulmonary metastases have been documented, since ${ }^{131} I$ therapy will be necessary $[2-4,7,8]$. We have observed that patients with more aggressive and initially extensive local/regional disease are those most likely to present with pulmonary metastases or to have such spread later. Patients with pulmonary metastases can often be given palliative treatment for long periods or cured by ${ }^{131} 1$ therapy,

Patients can die of childhood DTC. There have been 4 deaths in our 54-year experience. Two occurred in terminally ill 3-year-olds treated only with palliative tracheostomies. The other 2 death were of long-term survivors (average survival 18.5 years; range 7-30 years). All 4 patients who died were 11 years old or younger at the time of initial diagnosis. Similarly, in the series described by Schlumberger and coworkers [8], deaths from childhood DTC occurred only in children 9 years old or younger at initial treatment. No deaths have occurred among long-term survivors treated at our institution in the past 20 years.

At our center, ${ }^{131} \mathrm{I}$ remains an invaluable adjunct in the treatment of DTC. Patients are scanned 6 weeks after total or completion thyroidectomy. Those with uptake in the thyroid bed, lateral neck, or lungs are treated with a therapeutic dose, which is repeated as necessary to treat residual metastatic disease. Seventy-three $(82 \%)$ of 89 patients have been given adjuvant ${ }^{131} \mathrm{I}$ therapy, with the average being $180 \mathrm{mCl}$. Larger total doses have been used in patients with pulmonary metastases. The 2 long-term survivors with pulmonary metastases who died had good palliation of their distant disease. The 4 paptients with pulmonary metastases seen since 1971 have received an average total dose of $351 \mathrm{mCi}$; all are alive.

In the past 20 years, we have become more selective with respect to our use of postoperative ${ }^{131} I$ therapy. We no longer treat patients who have uptake only in the thyroid bed. As a result, the proportion of patieints treated with ${ }^{131}$ I has fallen from $88 \%$ before 1971 to $73 \%$ since then. Radioiodine has been used successfully to treat residual microscopic disease, such as that around recurrent laryngeal nerves and in nonpalpable lymph nodes. It also provides excellent long-term results in patients with pulmonary metastases. Its selective use should be continued in most cases of childhood DTC and in many adult cases as well.

Monitoring patients with DTC for persistent or recurrent disease has been made considerably easier by the development of the serum thyroglobulin assay. We have found the normal thyroglobulin level to range from 0.0 to $60.0 \mathrm{ng} / \mathrm{ml}$. Patients who have undergone total thyroidectomy and have no residual disease should have a level $5 \mathrm{ng} / \mathrm{ml}$. For the past 7 years we have monitored all patients (including adults) with use of postoperative thyroglobulin assays, which we have found to represent a sensitive method for detecting persistent or recurrent disease.

One case, for example, involved a 5 -year-old girl who underwent total thyroidectomy and lymph node sampling for a papillary carcinoma $(2.5 \times 2.5 \mathrm{~cm})$ in the right lobe of the thyroid. Two affected nodes were excised. Six weeks after surgery, the patient was treated with $56 \mathrm{mCi}$ of ${ }^{131} \mathrm{I}$. The baseline thyroglobulin at 6 months was $25.5 \mathrm{ng} / \mathrm{ml}$. An ${ }^{131}$ I scan showed uptake in the midline area of the neck and lungs, and a chest roentgenogram showed densities at the base of both lungs.

Three months later, even though there were no palpable abnormalities, the right side of the neck was explored; 3 more involved nodes were excised. The patient's thyroglobulin level continued to increase, however, to a high of $62.2 \mathrm{ng} / \mathrm{ml}$, presumably because of her pulmonary metastases. The patient was treated with 2 additional courses of ${ }^{131} \mathrm{I}$, for a total dose of $326 \mathrm{mCi}$. Before her most recent dose, her thyroglobulin level had fallen to $24.6 \mathrm{ng} / \mathrm{ml}$.

Although the treatment of differentiated thyroid carcinoma in children and adults remains controversial, we continue to believe strongly that total thyroidectomy is the best management option. It is safe when performed by a skilled surgeon. When used with appropriate cervical lymph node dissection, it is essential not only for controlling cancer in the neck but for allowing ${ }^{131} \mathrm{I}$ therapy of microscopic regional and distant metastases. We will continue to advocate the use of total thyroidectomy as initial therapy until a biologic marker that identifies aggressive disease is found. Under the present circumstances, however, we believe that the most conservative treatment for childhood thyroid carcinoma is total thyroidectomy.

\section{Résumé}

Entre 1936 et 1990,89 enfants et adolescents ( 72 filles et 17 garons) ont été traités pour cancer différencie de la thyroide au Centre Médical de l'Université de Michigan. Cinquante huit d'entre eux ont fait l'objet d'une publication en 1971. Trente de ces patients $(34 \%)$ avaient eu une radiothérapie externe au niveau de la tête et/ou du cou, mais ce facteur n'a été retrouvé que chez un des 33 derniers patients (3\%). Les patients vus entre 1971 et 1990 avaient une maladie moins avancée. Pendant cette période, le taux d'adénopathies cervicales palpables est passée de 63 à $36 \%$; le pourcentage de patients ayant une infiltration locale, de 31 à $6 \%$, et celui de métastases pulmonaires de 19 à $6 \%$. L'incidence des métastases ganglionnaires cervicales, par contre, est restée de $88 \%$ depuis 54 ans. Le cancer était papillaire ou folliculaire dans $93 \%$ des cas. Soix- 
ante-neuf patients (89\%) ont eu une thyroïdectomie totale, soit d'emblée soit secondairement. La thérapeutique des métastases ganglionnaires a varié depuis l'exérèse régionale et le curage ganglionnaire cervical. Le taux global de paralysie récurrentielle et de l'hypoparathyroïde était de $4.5 \%$, mais aucune de ces deux complications n'a été observée pour les enfants opérés dans notre centre au cours des 25 dernières années. Parmi les 33 derniers patients, le taux de tissu résiduel ou de récidive était bas. Dans $21 \%$ des cas, il persistait du tissu néoplasique après chirurgie, sans récidive. Quatre-vingt pour cent de ces patients ont eu un traitement par l'iode 131. La mortalité à distance était de $2.2 \%$. Nous continuons de recommander une thyroïdectomie totale, une lymphadénectomie cervicale et une iodothérapie post-opératoire par l'iode 131 comme le traitement les plus conservateurs du cancer différencié de la thyroïde chez l'enfant.

\footnotetext{
Resumen

Ochenta y nueve niños y adolescentes (72 de sexo femenino y 17 de sexo masculino) fuiron tratados por carcinoma tiroideo diferenciado en el Centro Médico de la Universidad de Michigan; 58 de estos pacientes fueron reportados por primera vez en 1971. Treinta pacientes (34\%) tenían historia de irradiación a la cabeza y el cuello; sin embargo, solamente uno de los últimos $33(3 \%)$ presentó tal historia. Los pacientes vistos entre 1971 y 1990 exhibían enfermedad menos avanzada que aquellos vistos previamente. Así mismo, la incidencia de adenopatías cervicales palpables descendió de $63 \%$ a $36 \%$, la de infiltración local por cáncer primario de $31 \%$ a $6 \%$ y la de metástasis pulmonares iniciales de $19 \%$ a $6 \%$. La incidencia de metástasis ganglionares cervicales se ha mantenido en $88 \%$ por 54 años. La variante papilar o folicular del carcinoma papilar se encontró en $93 \%$ de los pacientes de la serie. Setenta y nueve pacientes (89\%) fueron sometidos a toroidectomía total o a reoperación para completar la tiroidectomía total. El manejo quirúrgico de las metástasis linfáticas varió desde la resección regional de los ganglios hasta la disección radical del cuello. La tasa global de lesión accidental, permanente o temporal, del nervio recurrente laríngeo y de hopoparatiroidismo fue $4.5 \%$, aunque ninguna de estas complicaciones ha ocurrido en un niño o en un adoles-
}

cente sometido a cirugía en nuestro centro médico en los últimos 25 años. Los últimos 33 pacientes exhibieron una tasa reducida de persistencia o de recurrencia local/regional. La persistencia ganglionar cervical se presentó en $21 \%$ de los casos; no hubo recurrencias tiroideas. Ochenta y dos por ciento de los pacientes recibió ${ }^{131} \mathrm{I}$. La tassa de mortalidad a largo plazo fui $2.2 \%$. Nuestro grupo continúa preconizando tiroidectomía total, disección ganglionar cervical y terapia postoperatoria con ${ }^{131}$ I como la modalidad terapéutica más conservadora en carcinoma diferenciado de la glándula tiroidea en la niñez.

\section{Acknowledgments}

We would like to thank Linda Armstrong, Renee J. Robillard, Robert Walkama, and the staff of the University of Michigan Hospitals' Cancer Registry.

\section{References}

1. Winship, T., Rosvoll, R.: Thyroid carcinoma in children: Final report on a 20-year study. Clin. Proc. Child. Hosp. D.C. 26:11, 1970

2. Harness, J.K., Thompson, N.W., Nishiyama, R.H.: Childhood thyroid carcinoma. Arch. Surg. 10:278, 1971

3. Buckwalter, J.A., Gurll, N.J., Thomas, C.G., Jr.: Cancer of the thyroid in youth. World J. Surg. 5:15, 1981

4. Ceccarelli, C., Pacini, F., Lipppi, F., Elisei, R., Arganini, M., Miccoli, P., Pinchera, A.: Thyroid cancer in children and adolescents. Surgery 104:1143, 1988

5. Zimmerman, D., Hay, I.D., Gough, I.R., Goellner, J.R., Ryan, J.J., Grant, C.S., McConahey, W.M.: Papillary thyroid carcinoma in children and adults: Long-term follow-up of 1039 patients conservatively treated at one institution during three decades. Surgery 104:1157, 1988

6. LaQuaglia, M.P., Corbally, M.T., Heller, G., Exelby, P.R., Brennan, M.F.: Recurrence and morbidity in differentiated thyroid carcinoma in children. Surgery 104:1149, 1988

7. Goepfert, H., Dichtel, W.J., Samaan, N.A.: Thyroid cancer in children and teenagers. Arch. Otolaryngol. 110:72, 1984

8. Schlumberger, M., DeVathaire, F., Travagli, J.P. Vassal, G., Lemerle, J., Permentier, C., Tubiana, M.: Differentiated thyroid carcinoma in childhood: Long term follow-up of 72 patients. J. Clin. Endocrinol. Metab. 65:1088, 1987

9. Frankenthaler, R.A., Sellin, R.V., Cangir, A., Goepfert, H.: Lymph node metastasis from papiliary-follicular thyroid carcinoma in young patients. Am. J. Surg. 160:341, 1990

\section{Invited Commentary}

\author{
Paul Lo Gerfo, M.D. \\ Department of Surgery, Columbia Presbyterian Medical Center, New \\ York City, New York, U.S.A.
}

\footnotetext{
This study, as those of others, points out the fact that there are few physicians who have ever gained extensive experience with differentiated carcinoma of the thyroid in children. Despite the relatively large size of this series, the authors treated less than 2 patients per year with differentiated thyroid cancer. In view of this it is highly unlikely that any radomized studies will ever be available to determine the best treatment of this cancer based on the stage of the disease and long term survival.
}

This study is in agreement with others which show that children have a relatively high incidence of disease outside the thyroid bed. In addition, the incidence of distant metastatic disease for differentiated cancer appears to be higher than that seen in most adults. Based on the high incidence of bilateral cervical lymphadenopathy and pulmonary metastases seen in many series, many centers continue to advocate total thyroidectomy or near total thyroidectomy in patients $<16$ years of age. This is because radioactive iodine can easily be used in the postoperative period to treat distant or unresectable disease.

I would agree with the authors that one of the main goals of treatment is to clean out the central compartment of the neck without causing permanent hypoparathyroidism and/or laryngeal nerve injury. The extent of disease and direct invasion of the nerve sometimes make complete resections difficult and occasionally residual disease is left. If total thyroidectomy is 